\title{
PRODUCTION COMPONENTS OF CRAMBE IN PARAIBA SEMI-ARID REGION WITH NITROGEN FERTILIZATION AND DIFFERENT SPACINGS
}

\author{
COMPONENTES DE PRODUÇÃO DE CRAMBE NO SEMIÁRIDO PARAIBANO \\ COM ADUBAÇÃO NITROGENADA E DIFERENTES ESPAÇAMENTOS
}

\author{
Luan Dantas de OLIVEIRA ${ }^{1}$; Lúcia Helena Garófalo CHAVES ${ }^{{ }^{*}}$; \\ Antonio Ramos CAVALCANTE ${ }^{\mathbf{1}}$; Felipe Guedes de $\operatorname{SOUZA}^{\mathbf{1}}$; \\ Ana Carolina Feitosa de VASCONCELOS ${ }^{1}$; Jucilene Silva ARAUJO ${ }^{2}$ \\ 1. Universidade Federal de Campina Grande, Programa de Pós-Graduação em Engenharia Agrícola, Campina Grande, PB, Brasil. \\ lhgarofalo@hotmail.com*; 2. Instituto Nacional do Semiárido - INSA/MCTIC, Campina Grande, PB, Brasil. \\ Jucilene.araujo@insa.gov.br
}

\begin{abstract}
Crambe (Crambe abyssinica H.), a promising species in the production of biodiesel, has low planting cost, high oil content and easy extraction, besides being an alternative for the crop rotation system. The objective of this study was to evaluate the effects of nitrogen fertilization and line spacing on the production components and yield of the crambe crop under semi-arid conditions. The study was conducted under field conditions in the experimental area of the National Semi-Arid Institute-INSA, located in the city of Campina Grande-PB. The experimental design was a randomized complete block design in $4 \times 2$ factorial scheme, consisting of four nitrogen doses $\left(30,60,90,120 \mathrm{~kg} \mathrm{ha}^{-1}\right)$ with two spacings between planting lines ( 0.20 and 0.40 meters) with three replications, totaling 24 experimental plots. The evaluated parameters were: number of siliques per plant, dry weight of shoots, number of branches (primary and secondary), primary stem length, number of siliques per stem, mass of 1000 grains and productivity. The data were submitted to analysis of variance, in which the nitrogen doses (quantitative factor) were compared by regression analysis. The different spacings were compared by means of a t-test at the 0.05 probability level by using statistical software SISVAR version 5.2. Nitrogen fertilization at $0.40 \mathrm{~m}$ spacing between the planting lines led to the best results for the production components, and the highest productivity was obtained at $0.20 \mathrm{~m}$ spacing of with nitrogen fertilization of $120 \mathrm{~kg} \mathrm{ha}^{-1}$.
\end{abstract}

KEYWORDS: Crambe abyssinica H. Planting density. Mineral nutrition.

\section{INTRODUCTION}

Progress from biodiesel is relevant mainly when used in regions where agricultural development is deficient, such as the semi-arid region of Northeast Brazil. In this region, there are recurrent periods of drought, little diversification of crops adapted to edaphoclimatic conditions and absence of productive systems compatible with those already adopted by farmers in this region (LIMA, 2007). Thus, to establish a crop in the national energy matrix, studies are needed on its agronomic and technological aspects, such as productivity, oil content, nutrition, and management, in a way that satisfies the needs of the producer and market requirements (SQUIZATO, 2008).

Crambe (Crambe abyssinica Hochst), from the Brassicacea family, is native to the Mediterranean, and is an alternative for the production of raw material for biodiesel, as this crop shows great tolerance to drought, short growing cycle and relatively low production costs
(ONOREVOLI, 2012). In addition, it has high stability to oxidation, which imparts advantages such as greater resistance to degradation, consequently, resulting in the benefits of storage time, since the biodiesel coming from other vegetable oils has instability regarding oxidation (BISPO et al. al., 2010). In turn, crambe exhibits a high precocity with flowering from 35 days after sowing (DAS), being harvested at the end of the cycle, between 85-90 DAS, depending on its maturation. The oil content in the grain varies from $26 \%$ to $38 \%$, containing $55 \%$ of erucic acid, making the oil toxic to animals, which is an advantage because this oil does not compete with oils destined for the food sector (PITOL; BROCH; ROSCOE, 2010).

However, it is known that crambe requires high amounts of nitrogen, due to the high protein content in the grains (SOUZA et al., 2009). Nitrogen $(\mathrm{N})$ is present in the constitution of several components of the plant cell, including nucleic acids and amino acids, as well as in the composition of the chlorophyll molecule, besides aiding in protein 
synthesis reactions. Thus, when under conditions of insufficiency, it negatively affects the process of cell division (TAIZ; ZEIGER, 2004). In the oilseeds, N acts on the metabolism of the synthesis of compounds of seed reserves, affecting oil production, as well as the protein content in the grains (CASTRO et al., 1999).

In addition to the nutritional factor, the spatial arrangement with adequate spacing between the sowing lines is an important cultivation practice in increasing a satisfactory productivity (VON PINHO et al., 2008). Crops, in turn, manifest their maximum production potential in conditions where there are no stress factors, coupled with the maximum uptake of solar radiation and nutritional absorption, justifying the indispensability of adequate spacing adjustments, according to the agronomic needs of the crop. Thus, such adjustments may contribute to their maximum morphological expression and, consequently, to their yields (ARGENTA; SILVA; SANGOI, 2001).

Based on this assumption, the present study had as objective to evaluate the effects of nitrogen fertilization and spacing between rows on the production components and yield of the crambe crop under semi-arid conditions in the state of Paraíba, Brazil.

\section{MATERIAL AND METHODS}

The experiment was conducted from March to July 2018, at the Experimental Farm of the National Semi-Arid Institute-INSA, located in the Southwestern Zone of Campina Grande-PB $\left(07^{\circ}\right.$ $16 ' 38$ "S, 35 58'05" $\mathrm{W}$ and $550 \mathrm{~m}$ altitude). The soil was classified as clay loam, with granulometry values of 661,185 , and $154 \mathrm{~g} \mathrm{~kg}^{-1}$ of sand, silt and clay, respectively.

The climate of the region is BSh, according to Köppen, defined as hot semi-arid with average temperature of $22.9{ }^{\circ} \mathrm{C}$. During the experimental period, minimum and maximum temperatures were $16.6^{\circ} \mathrm{C}$ and $28.6^{\circ} \mathrm{C}$, respectively. The mean rainfall index was $49.78 \mathrm{~mm}$, and the wettest period occurred at the beginning of the crop cycle, during the 15 days after sowing (DAS), reaching $91 \mathrm{~mm}$; on the other hand, at the end of the cycle, during the maturation period, before the harvest, a precipitation of $0.6 \mathrm{~mm}$ was observed. The daily values of these parameters during the conduction of the experiment are presented in Figure 1.

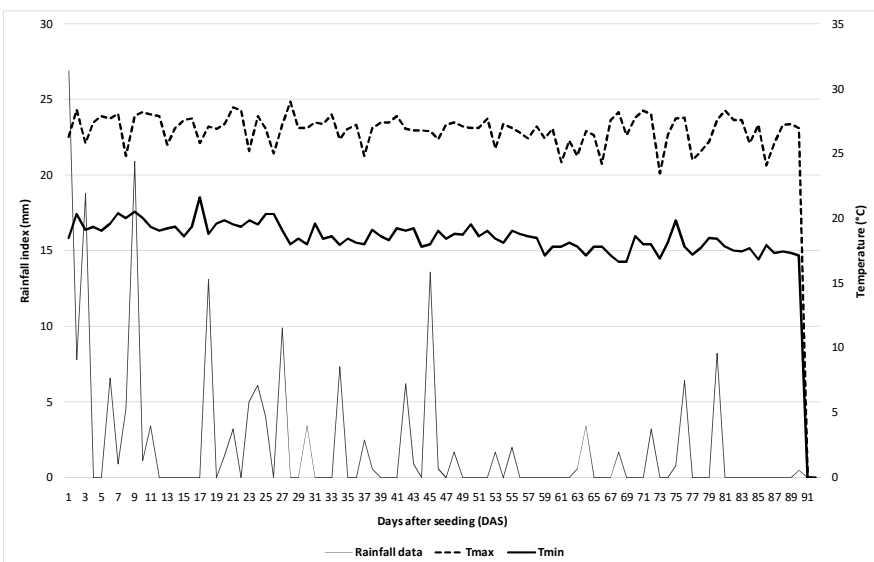

Figure 1. Weather characteristics from April to July 2018.

(Data source: INSA Meteorological Station).

The analysis of the soil sample of the experimental area, taken before the experiment was set up, at depth of 0 to $20 \mathrm{~cm}$, according to Embrapa (2011), showed the following results:pH $\left(\mathrm{H}_{2} \mathrm{O}\right)=$ 5.3; organic matter $=18.1 \mathrm{~g} \mathrm{dm}^{-3} ; \mathrm{P}=6.0 \mathrm{mg} \mathrm{dm}^{-3}$; $\mathrm{K}=0.32 \mathrm{cmol}_{\mathrm{c}} \mathrm{dm}^{-3} ; \mathrm{Ca}=1.95 \mathrm{cmol}_{\mathrm{c}} \mathrm{dm}^{-3} ; \mathrm{Mg}=$ $1.34 \mathrm{cmol}_{\mathrm{c}} \mathrm{dm}^{-3} ; \mathrm{Na}=0.11 \mathrm{cmol}_{\mathrm{c}} \mathrm{dm}^{-3} ; \mathrm{H}=2.80$ $\mathrm{cmol}_{\mathrm{c}} \mathrm{dm}^{-3} ; \mathrm{Al}=0.20 \mathrm{cmol}_{\mathrm{c}} \mathrm{dm}^{-3}$.

The experimental design was a randomized block design in $4 \times 2$ factorial scheme, consisting of four nitrogen doses $\left(30 ; 60 ; 90 ; 120 \mathrm{~kg} \mathrm{ha}^{-1}\right)$ and two spacings between planting lines $(0.20$ and 0.40 meters) with three replications, totaling twenty four plots. The experiment was distributed in a 12-mwide, 26-m-long rectangular area, totaling $312 \mathrm{~m}^{2}$. The plots, with $2 \mathrm{~m}^{2}$ of area $(2 \mathrm{~m} \mathrm{x} 1 \mathrm{~m})$, were formed by 10 and 5 lines, spaced by $0.2 \mathrm{~m}$ and $0.4 \mathrm{~m}$, respectively, with ten plants per linear meter, and 5 plants were evaluated in the eight and three lines regarded as useful, respectively.

Nitrogen doses as ammonium sulfate were split into three portions, at 15, 30 and 45 DAS, by applying $9.52 \mathrm{~g}, 19.04 \mathrm{~g}, 28.56 \mathrm{~g}$ and $38.08 \mathrm{~g}$ per plot (corresponding to $30 ; 60 ; 90 ; 120 \mathrm{~kg} \mathrm{~N} \mathrm{ha}^{-1}$, 
respectively). Phosphorus and potassium as single superphosphate and potassium chloride, respectively, were applied before planting, using 66.7 and 20.7 grams per plot, corresponding to 60 $\mathrm{kg} \mathrm{ha}^{-1}$ of each fertilizer.

Crambe, cultivar 'FMS Brilhante', provided by the Mato Grosso do Sul Foundation - FMS, was sown on April 23, 2018, using on average $12 \mathrm{~kg} \mathrm{ha}^{-1}$ of seeds, alternating between the $0.20 \mathrm{~m}$ and $0.40 \mathrm{~m}$ spacing. Thinning was done at 10 DAS, resulting in 10 plants per linear meter. Harvest was performed manually at 91 DAS, and the material of each treatment was separated and placed in identified plastic bags.

The following phenometric characteristics were evaluated in five plants per plot: number of siliques per plant (NSP) - whole plant silique count; number (NPS) and length of primary stems (LPS); number of secondary stems (NSS); number of siliques per stem (NSP); weight of 1000 siliques (W1000) - determined on a precision scale, correcting grain moisture to $13 \%$, in grams; grain yield - the entire plot was harvested, weighed and the values were extrapolated to $\mathrm{kgha}^{-1}$ and corrected to $13 \%$ grain moisture content; dry mass of plants after being harvested, the plants were dried in an oven with forced air circulation at $65^{\circ} \mathrm{C}$ for 72 hours and weighed on a precision scale.

The data were submitted to analysis of variance, in which the nitrogen doses (quantitative factor) were compared by regression analysis. The different spacings were compared by means of a ttest at the 0.05 probability level using statistical software SISVAR version 5.2 (FERREIRA, 2011).

\section{RESULTS AND DISCUSSION}

Based on the results of the analysis of variance (Table 1), it was observed that the variables number of siliques per plant (NSP), shoot dry mass (SDM), number of primary stems (NPS), length of primary stem (LPS), number of secondary stems (NSS) and weight of 1000 siliques (W1000) were significantly influenced $(\mathrm{p}<0.01)$ by the nitrogen doses and by the different spacings. The interaction between these factors significantly influenced $(\mathrm{p}<0.01)$ only NPS.

Table 1. Summary of the ANOVA for the number of siliques per plant (NSP), shoot dry mass (SDM), number of primary stems (NPP), length of primary stem (LPS), number of secondary stems (NSS), number of siliques per stem (SL) and weight of 1000 siliques (W1000) of crambe, using different doses of nitrogen and spacings under field conditions.

\begin{tabular}{|c|c|c|c|c|c|c|c|c|}
\hline \multirow{2}{*}{$\begin{array}{l}\text { Source } \\
\text { variation }\end{array}$} & \multirow[b]{2}{*}{ DF } & \multirow[b]{2}{*}{$\mathrm{NSP}^{1}$} & \multirow[b]{2}{*}{$\mathrm{SDM}^{1}$} & \multicolumn{3}{|l|}{ T-test } & \multirow[b]{2}{*}{$\mathrm{SL}^{1}$} & \multirow[b]{2}{*}{ W1000 } \\
\hline & & & & $\mathrm{NPS}^{1}$ & LPS $^{1}$ & $\mathrm{NSS}^{1}$ & & \\
\hline $\mathrm{N}$ & 3 & - & & ** & & ** & ns & ** \\
\hline $\mathrm{S}$ & 1 & ** & ** & ** & ** & ** & ns & ** \\
\hline Block & 2 & ns & ns & ns & ns & ns & ns & ns \\
\hline $\mathrm{N} \times \mathrm{S}$ & 3 & ns & ns & ** & ns & ns & ns & ns \\
\hline Linear & 1 & ** & ** & ** & * & ** & ns & * \\
\hline Quadratic & 1 & ** & ** & ** & ** & ** & ns & ns \\
\hline Error & 112 & 0.102 & 0.022 & 0.015 & 0.030 & 0.068 & 0.088 & 0.028 \\
\hline $\mathrm{CV}$ & $\%$ & 11.35 & 15.84 & 10.45 & 10.68 & 16.88 & 18.54 & 19.36 \\
\hline
\end{tabular}

The nitrogen doses applied significantly influenced the number of siliques, which increased linearly (Figure 2A). There was a $91.44 \%$ increase in the number of siliques between the lowest $(30 \mathrm{~kg}$ $\left.\mathrm{ha}^{-1}\right)$ and highest $\left(120 \mathrm{~kg} \mathrm{ha}^{-1}\right)$ nitrogen doses. These results corroborate Ledur, Chaves and Fernandes (2016), who conducted a study in the western region of Paraná and observed a significant effect of nitrogen fertilization on the number of siliques; however, at the dose of $120 \mathrm{~kg} \mathrm{ha}^{-1}$, a total of 368.52 siliques per plant was produced, $67.21 \%$ lower than that found in this study. According to Sampaio et al. (2016), crambe has a high potential for responsive to nitrogen fertilization, including the use of high doses.

The number of siliques per plant also varied significantly according to the different spacings, that is, there were around 1109 and 602 siliques at the spacings 0.40 and $0.20 \mathrm{~m}$, respectively, an increase of $84.17 \%$ (Figure 2B). According to Kruger et al. (2011), in canola, a crop of the same family as crambe, Brassicaceae, the modification in the spatial arrangement of plants through suitable spacing and densities can be an alternative to reach better yield in the number of siliques. However, according to Chavarria et al. (2011), there is a maximum limit of 
plants in a given space due to the physiological competition between them. Therefore, the ideal equidistance between plants is an important alternative to obtain good production of siliques per plant.

The shoot dry mass of plants submitted to $120 \mathrm{~kg} \mathrm{ha}^{-1}$ of $\mathrm{N}$ was $56.03 \%$ higher compared to those grown with the dose of $30 \mathrm{~kg} \mathrm{ha}^{-1}$ (Figure 2C). These results corroborate Vechiatto and Fernandes (2011), who obtained significant difference between doses of $\mathrm{N}\left(0 ; 80 ; 120 \mathrm{~kg} \mathrm{ha}^{-1}\right)$ applied as topdressing in crambe, positively affecting the weight of dry mass. Similarly, Souza and Chaves (2017) observed an increase in shoot dry mass as a function of nitrogen fertilization $(30,60,90,120 \mathrm{~kg}$

A

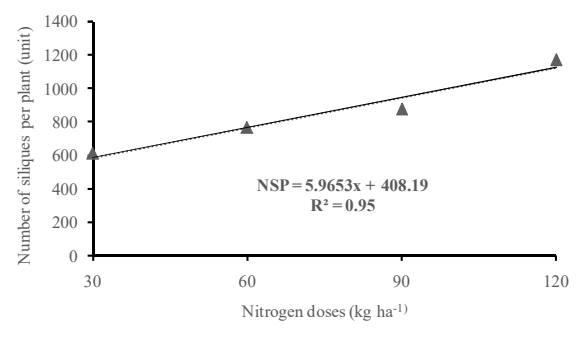

C

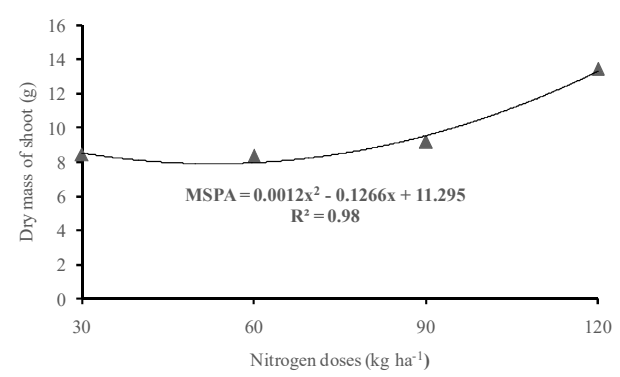

$\mathrm{E}$

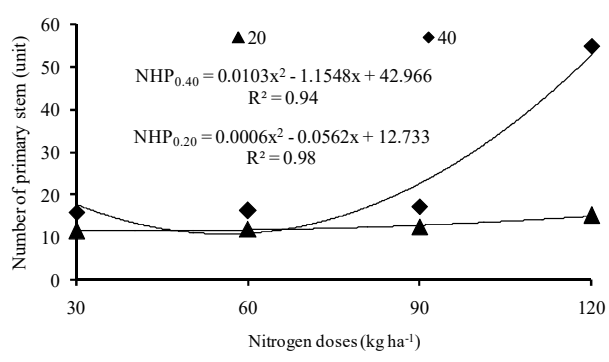

OLIVEIRA, L. D. et al.

$\mathrm{ha}^{-1}$ ), thus confirming the importance of $\mathrm{N}$ in the production of dry matter, and consequently in the development of the crop.

The dry mass of shoot, regardless of the doses of $\mathrm{N}$, was greater at the spacing corresponding to $0.40 \mathrm{~m}$, that is, $12.38 \mathrm{~g}$ (Figure 2D), a value $68.9 \%$ greater than the $7.33 \mathrm{~g}$, obtained at the smallest spacing, $0.20 \mathrm{~m}$. As the dry mass of shoot is closely linked to the number of leaves, Bandeira (2013) verified in canola that the limitation of shoot and its components is a limiting morphological characteristic for the productivity of this crop. Thus, the low development of crambe shoot can indicate a lower production.

B

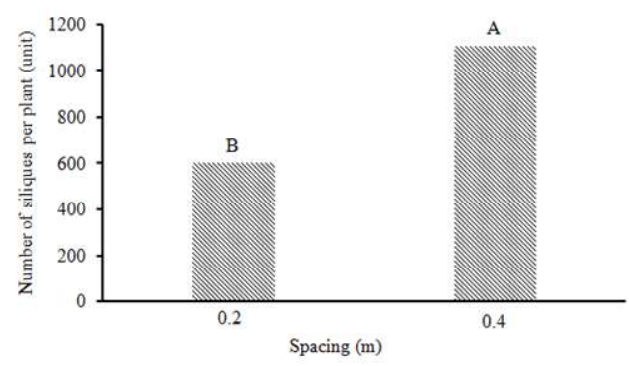

$\mathrm{D}$

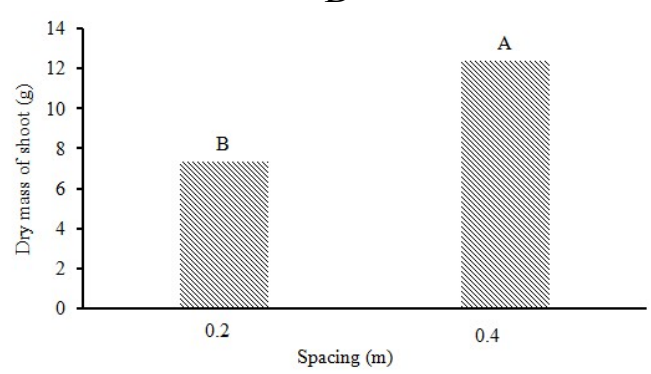

$\mathrm{F}$

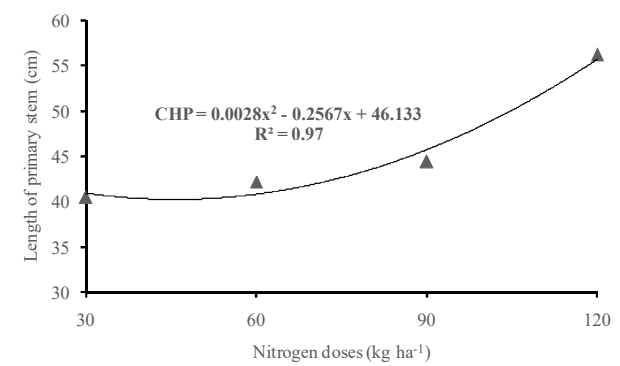

Figure 2. Number of siliques per plant as a function of different nitrogen doses (A) and different spacings (B); dry mass of shoot per plant as a function of different doses of nitrogen $(\mathrm{C})$ and different spacings (D); number of primary stems in the interaction nitrogen doses vs spacing (E); length of primary stem as a function of different doses of nitrogen $(F)$ in the cultivation of crambe plants in the field.

For the number of primary stems (NPS) (Figure 2E), there was a significant effect of the interaction between nitrogen doses and spacing. The NPS at the $0.40 \mathrm{~m}$ spacing graphically exhibited a quadratic behavior, in which, from the dose of $60 \mathrm{~kg}$ $\mathrm{ha}^{-1}$, there was a progressive increase in the number of primary stems. However, at the spacing of 0.20 $\mathrm{m}$, a linear behavior was observed in the results referring to the analyzed variable, in which there was a $26.25 \%$ increase in NPS when the values of 
Production components...

the lowest $\mathrm{N}$ dose $\left(30 \mathrm{~kg} \mathrm{ha}^{-1}\right)$ were compared to those of the highest $\mathrm{N}$ dose $\left(120 \mathrm{~kg} \mathrm{ha}^{-1}\right)$. Thus, similarly, at the $0.40 \mathrm{~m}$ spacing, the increase was $199.62 \%$ higher compared to the lowest $\mathrm{N}$ dose.

The application of $\mathrm{N}$ influenced the length of the primary stems (Figure 2F), and the largest length $(55.65 \mathrm{~cm})$ was found at the highest $\mathrm{N}$ dose. Thus, in this study, it is noticed that there is a direct relation between the number of siliques and the number and length of primary stems; thus, the vegetative development of the crop is correlated with its production. In this crop, the study of the performance in stem formation is important, since it helps in the interception of solar radiation. According to the Canola Council of Canada cited by Chavarria et al. (2011), canola stems play an important photosynthetic role at the beginning of silage maturation, as the leaf area index begins to decrease after the beginning of the flowering stage. For Tipewa (2017), it is important to keep variables such as number of primary and secondary stems and branch length, as they are indirectly influencing crop yield. So, it is notorious that crambe expresses its potential as the greatest nutritional supply occurs, or adequacy in the arrangement, thus mitigating the effects caused by competition between plants.

The length of primary stems was also influenced by the spacing of the planting lines (Figure 3A), and the best performance, referring to $0.40 \mathrm{~m}$, reached $53.03 \mathrm{~cm}$ in height, which was $37.23 \%$ higher than that found at the spacing of 0.20 $\mathrm{m}$, in which the plants reached an average of 38.65 $\mathrm{cm}$. These results corroborate Tomm (2007), who recommends spacing up to $0.45 \mathrm{~m}$ and a minimum density of 40 plants $\mathrm{m}^{-2}$ in the canola crop to ensure a satisfactory yield.

Nitrogen fertilization influenced in a quadratic way the number of secondary stems (Figure 3B), which reached 53.61 stems with $120 \mathrm{~kg}$ $\mathrm{ha}^{-1}$ of $\mathrm{N}$. This value was about $40.08 \%$ higher in comparison to the 38.27 stems produced with $30 \mathrm{~kg}$ $\mathrm{ha}^{-1}$ of N. Similar results were obtained by Pereira et al. (2015), who observed that the increase in the number of branches was significantly influenced as a function of the $\mathrm{N}$ doses of $0,30,60,90,120 \mathrm{~kg} \mathrm{ha}^{-}$ 1 .

At the spacings of 0.20 and $0.40 \mathrm{~m}$, the number of secondary stems (Figure 3C) showed significant behavior. At the spacing of $0.40 \mathrm{~m}(55.23$ $\mathrm{cm}$ ), of the value was $79.47 \%$ higher than that found at the spacing of $0.20 \mathrm{~m}(30.78 \mathrm{~cm})$. According to Kruger et al. (2011), in the rapeseed, also a crop of the Brassicaceae family, the smaller competition
OLIVEIRA, L. D. et al.

between plants favors the greater number of branches and, consequently, a greater number of siliques.

The weight of 1000 siliques under different doses of $\mathrm{N}$ increased linearly (Figure 3D), with a value of $10.01 \mathrm{~g}$ corresponding to $120 \mathrm{~kg} \mathrm{ha}^{-1}$ of N, which is $54.50 \%$ higher than the weight found in the treatment with the dose of $30 \mathrm{~kg} \mathrm{ha}^{-1}(6.48 \mathrm{~g})$. This result corroborates Rezende, Marques and Masetto (2015), who studied different levels of nitrogen and observed a significant effect on the grain mass as a function of $\mathrm{N}$. Rezende, Marques and Masetto (2015) stated that, in several production systems, the availability of nitrogen is one of the determining variables of production, influencing plant growthmore than any other nutrient.

The spacing of $0.40 \mathrm{~m}$ resulted in a higher mass of grains $(10.11 \mathrm{~g})$, surpassing by $58.46 \%$ the value obtained at the spacing of $0.20 \mathrm{~m}(6.38 \mathrm{~g})$ (Figure 3E). This result corroborates Freitas (2010), who assessed different spacings $(0.17 \mathrm{~m}, 0.34 \mathrm{~m}$ and $0.51 \mathrm{~m}$ ) and application of $14 \mathrm{~kg} \mathrm{ha}^{-1}$ of nitrogen and observed an increase in grain weight proportional to the increase in spacing.

The highest productivity (Figure 3F) was obtained with the highest dose of $\mathrm{N}$ applied, that is, $120 \mathrm{~kg} \mathrm{ha}^{-1}$ at the spacing of $0.20 \mathrm{~m}$, corroborating Kaefer et al. (2014), who observed the influence of $\mathrm{N}$ on rapeseed productivity. However, although the spacing of $0.40 \mathrm{~m}$ has benefited the previously discussed variables, the spacing of $0.20 \mathrm{~m}$ stood out for productivity, since the lower rate in the quantity of siliques is compensated by the greater number of plants per area. Bandeira (2013) obtained similar results in a study with canola at spacings of 0.17 ; $0.34 ; 0.51$ and $0.68 \mathrm{~m}$, finding the best grain yield at the $0.17 \mathrm{~m}$ spacing.

The high productivity observed in this work corroborates Sharghi et al. (2011), who worked with six cultivars of Brassica napus (L.) in the canola crop, at different sowing times, and found results ranging from 1,548 to $5,930 \mathrm{~kg} \mathrm{ha}^{-1}$. In addition to nitrogen fertilization and spacing, productivity was benefited by climatic factors such as temperature and rainfall. According to Souza and Chaves (2017), crambe represents an option of cultivation for regions of semi-arid and sub-humid climates in Northeast Brazil. Falasca et al. (2010), studying the appropriate agroclimatic delimitation for the crambe crop in Argentina, demonstrated that this crop shows greater aptitude for regions with temperatures between 15 and $25^{\circ} \mathrm{C}$, and can develop with $350 \mathrm{~mm}$ of annual precipitation. 


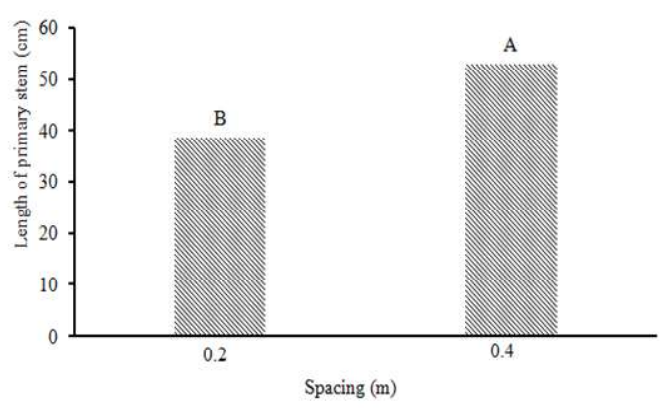

C

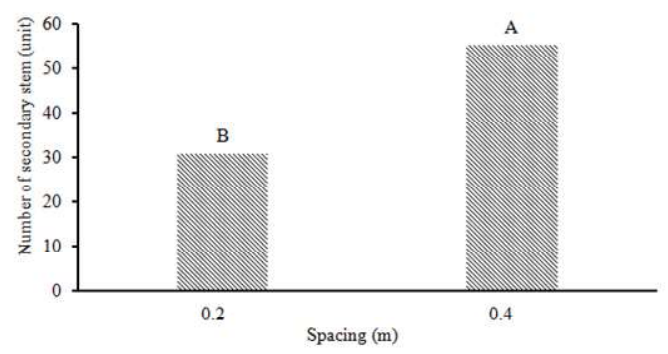

E

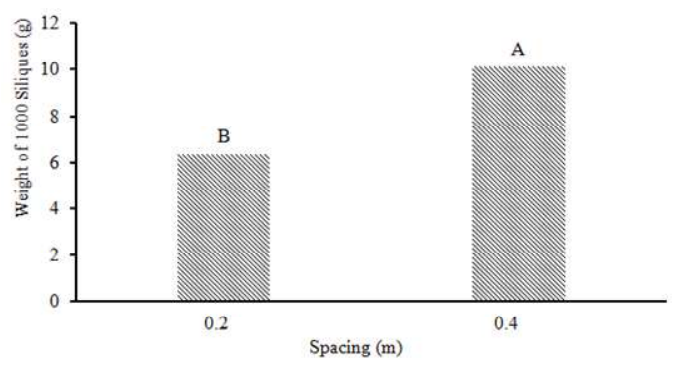

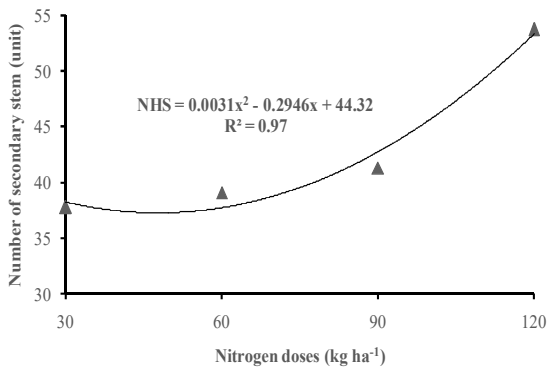

$\mathrm{D}$
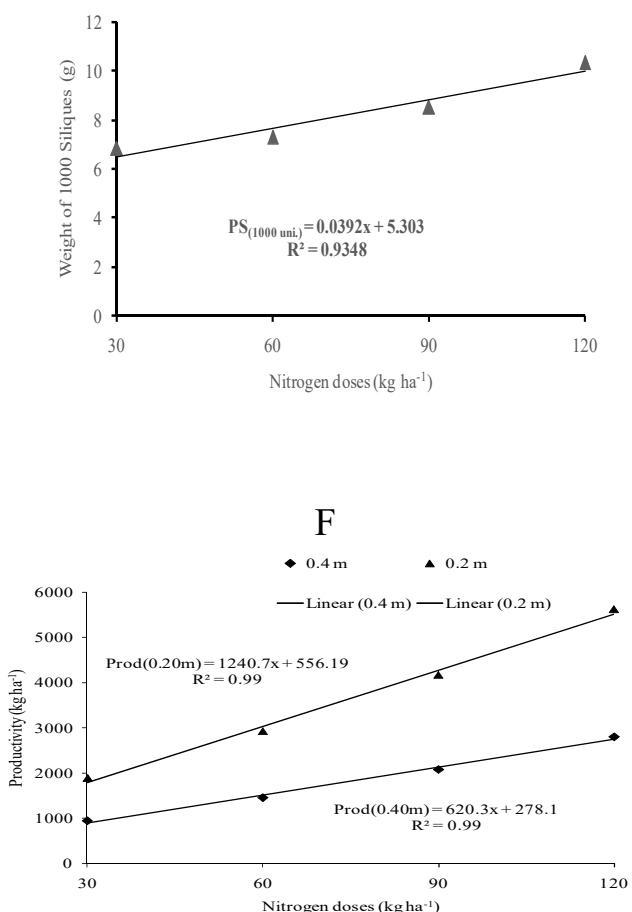

Figure 3. Length of primary stem as a function of different spacings (A); number of secondary stems as a function of nitrogen doses (B) and of different spacings (C); weight of 1000 siliques as a function of nitrogen doses (D) and of different spacings (E); productivity as a function of nitrogen doses at the different spacings $(\mathrm{F})$.

\section{CONCLUSIONS}

Nitrogen fertilization with spacing of 0.40 $\mathrm{m}$ between the planting lines led to the best results regarding the production components.
The highest productivity was obtained at the $0.20 \mathrm{~m}$ spacing with the nitrogen fertilization of 120 $\mathrm{kg} \mathrm{ha}^{-1}$.

RESUMO: O crambe (Crambeabyssinica H.), espécie promissora na produção de biodiesel, apresenta baixo custo de plantio, elevado teor de óleo e de fácil extração, além de ser alternativa para o sistema de rotação de culturas. Mediante a necessidade de conhecimento para ampliação do cultivo dessa espécie, este estudo teve como objetivo avaliar os efeitos da adubação nitrogenada e espaçamento entre linhas no cultivo nos componentes de produção e na produtividade da cultura do crambe em condições semiáridas. $\mathrm{O}$ estudo foi conduzido em condições de campo na área experimental pertencente ao Instituto Nacional do Semiárido-INSA, situado no município de Campina Grande-PB. O delineamento experimental utilizado foi em blocos casualizados, no esquema fatorial 4 x 2, sendo constituído de quatro doses de nitrogênio $\left(30 ; 60 ; 90 ; 120 \mathrm{~kg} \mathrm{ha}^{-}\right.$ $\left.{ }^{1}\right)$ com dois espaçamentos entre linhas de plantio $(0,20$ e 0,40 metros) e com três repetições, totalizando 24 parcelas experimentais. Os parâmetros avaliados foram: número de síliquas por planta, massa seca da parte 
aérea, número de ramificações (primárias e secundárias), comprimento de haste primária, número de silíquas por haste, massa de 1000 grãos e produtividade. Os dados obtidos foram submetidos à análise de variância, em que as doses de nitrogênio (fator quantitativo) foram comparadas por análise de regressão. Os diferentes espaçamentos foram comparados por meio de comparação de médias, pelo teste t, ao nível de 0,05 de probabilidade utilizando-se software estatístico SISVAR versão 5.2. A adubação nitrogenada sob espaçamento de $0,40 \mathrm{~m}$, entre as linhas de plantio, proporcionou os melhores resultados quanto aos componentes de produção, e a maior produtividade foi obtida no espaçamento referente a $0,20 \mathrm{~m}$ com a adubação nitrogenada de $120 \mathrm{~kg} \mathrm{ha}^{-1}$.

PALAVRAS-CHAVE: Crambe abyssinica H. Densidade de plantio. Nutrição mineral.

\section{REFERENCES}

ARGENTA, G.; SILVA, P. R. F. da; SANGOI, L. Arranjo de plantas em milho: análise do estado da arte. Ciência Rural, Santa Maria. v. 31, p.1075 1084, 2001. DOI: 10.1590/S0103 84782001000600027.

BANDEIRA, T. P. Ecofisiologia da canola Hyola 61 sob variações no arranjo de plantas. 2013. Dissertação (Mestrado) Universidade de Passo Fundo. Passo Fundo.

BISPO, A. S.; DELFINO, L. D.; COSTA, B. J.; SUCHEK. Caracterização de óleos vegetais extraídos mecanicamente sob condições variadas, visando a produção de biodiesel. In: CONGRESSO DA REDE BRASILEIRA DE TECNOLOGIA DE BIODIESEL, 4., e CONGRESSO BRASILEIRO DE PLANTAS OLEAGINOSAS, ÓLEOS, GORDURAS E BIODIESEL, 7., 2010, Belo Horizonte, MG. Anais... Belo Horizonte, MG: TECPAR, 2010.

CASTRO, C., BALLA, A.; CASTIGLIONI, V. B. R.; SFREDO, G. J. Levels and methods of nitrogen supply for sunflower. Scientia Agricola, Piracicaba. v.56, n.4, p.827-833, 1999. http://dx.doi.org/10.1590/S010390161999000400009.

CHAVARRIA, G.; TOMM, G. O.; MULLER, A.; MENDONÇA, H. F.; MELLO, N.; BETTO, M. S. Índice de área foliar em canola cultivada sob variações de espaçamento e de densidade de semeadura. Ciência Rural, Santa Maria. v. 41, n. 12, p. 2084-2089, 2011. http://dx.doi.org/10.1590/S0103-84782011001200008

EMBRAPA - Empresa Brasileira De Pesquisa Agropecuária. Centro Nacional de Pesquisa de Solos. Manual de métodos de análise de solo. 2. ed. Rio de Janeiro, 2011. 230p. (Documento 132).

FERREIRA, D. F. Sisvar: A computer statistical analysis system. Ciência e Agrotecnologia, Lavras.v. 35, n. 6, p. 1039-1042, 2011. http://dx.doi.org/10.1590/S1413-70542011000600001.

FREITAS, M. E. Comportamento agronômico da cultura do crambe (Crambe Abyssinica Hoechst) em função do manejo empregado. 2010. Dissertação (Mestrado) Universidade Federal da Grande Dourados. Dourados.

KAEFER, J. E.; GUIMARÃES, V. F.; RICHART, A.; TOMM, G. O.; MULLER, A. L. Produtividade de grãos e componentes de produção da canola de acordo com fontes e doses de nitrogênio. Pesquisa Agropecuária Brasileira, Brasilia. v. 49, n. 4, p. 273-280, 2014. DOI: 10.1590/S0100-204X2014000400005

KRÜGER, C. A. M. B.; SILVA, J. A. G.; MEDEIROS, S. L. P.; DALMAGO, G. A.; SARTORI, C. O.; SCHIAVO, J. Arranjo de plantas na expressão dos componentes da produtividade de grãos de canola. Pesquisa Agropecuária Brasileira, Brasilia. v. 46, p. 1448-1453, 2011. https://doi.org/10.1590/S0100-

204X2011001100005 
LEDUR, E. O.; CHAVES, L. H. G.; FERNANDES, J. D. Nitrogen and phosphorus on crambe development after off-season corn cultivation. Científica, Jaboticabal. v. 44, n. 2, p. 263-270, 2016.

http://dx.doi.org/10.15361/1984-5529.2016v44n2p263-270

LIMA, P. C. R. O biodiesel no Brasil e no mundo e o potencial do Estado da Paraíba. Biblioteca Digital da Câmara dos Deputados, 2007.

ONOREVOLI, B. Estudo do crambe abyssinica como fonte de matérias primas oleaginosas: óleo vegetal, ésteres metílicos e bio-óleo. 2012. Dissertação (Mestrado) Universidade Federal do Rio Grande do Sul, Porto Alegre.

PEREIRA, J. C. A.; SILVA, S. S.; CHAVES, L. H. G.; NEGREIROS, E. D. Resposta do crambe à fertilização mineral submetido a diferentes níveis de nitrogênio, fósforo e potássio. In: CONGRESSO TECNICO CIENTIFICO DA ENGENHARIA E DA AGRONOMIA, 2015, Fortaleza, CE. Anais... Fortaleza, CE, p.1-5, 2015.

PITOL, C.; BROCH, D. L.; ROSCOE, R. Tecnologia e Produção: Crambe. In: BROCH, D.L.; ROSCOE, R. Fertilidade do solo, adubação e nutrição do crambe. Maracaju: Fundação MS, 2010. p. 22-36.

REZENDE, R. K. S; MARQUES, R. F.; MASETTO, T. E. Características morfológicas e produtividade do crambe em função da adubação nitrogenada. Revista Agrarian, Dourados. v. 8, p. 279-286, 2015.

SAMPAIO, M. L.; BARZAN, R. R.; FREGONEZI, G. A. F. Doses de nitrogênio em cobertura na cultura do crambe em casa de vegetação. Revista de Agricultura, Piracicaba. v. 91, n. 2, p. 165-173, 2016.

https://doi.org/10.37856/bja.v91i2.1186

SHARGHI, Y.; RAD, A. H. S.; BAND, A, A.; NOORMOHAMMADI, G.; ZAHEDI, H. Yield and yield components of six canola (Brassica napus L.) cultivars affected by planting date and water deficit stress. African Journal of Biotechnology, v. 10, n. 46, p. 9309-9313, 2011. DOI:10.5897/AJB11.048.

SOUZA, A. D. V.; FÁVARO, S. P.; ÍTAVO, L. C.; ROSCOE, R. Caracterização química de sementes e tortas de pinhão manso, nabo-forrageiro e crambe. Pesquisa Agropecuária Brasileira, Brasília. v. 44, n.10, p.13281335, 2009. http://dx.doi.org/10.1590/S0100-204X2009001000017

SOUZA, R. S. DE; CHAVES, L. H. G. Crescimento e produção do crambe submetido a doses de nitrogênio e fósforo. Revista Espacios, Caracas. v. 38, n.8, p.1-24, 2017.

SQUIZATO, R. Fugindo da soja. Revista Biodiesel BR, v. 5, p. 49-53, 2008.

TAIZ, L.; ZEIGER, E. Fisiologia vegetal. 3.ed. Porto Alegre: Artmed, 2004. 719p.

TIPEWA, N. Produtividade de colza, girassol e soja em situações culturais diversas: variedades; datas de sementeira; e adubação azotada. 2017. Dissertação (Mestrado) Escola Superior Agrária de Bragança, Bragança.

TOMM, G. O. Indicativos tecnológicos para produção de canola no Rio Grande do Sul. Passo Fundo: Embrapa Trigo, 2007. 68p.

VECHIATTO, C. D.; FERNANDES, F. C. S. Aplicação de nitrogênio em cobertura na cultura do crambe. Cultivando o Saber, Cascavel. v.4, n.2, p.18-24, 2011.

VON PINHO, R. G.; GROSS, M. R.; STEOLA, A. G.; MENDES, M. C. Adubação nitrogenada, densidade e espaçamento de híbridos de milho em sistema de plantio direto na região Sudeste do Tocantins. Bragantia, Campinas. v.67, n.3, p.733-739, 2008.http://dx.doi.org/10.1590/S0006-87052008000300023. 